\title{
Effects of Trigger Point Dry Needling on Neuromuscular Performance and Pain of Individuals Affected by Patellofemoral Pain: A Randomized Controlled Trial [Corrigendum]
}
Ma YT, Li LH, Ha
Q, et al. $J$ Pain Res.
The authors apologize for this error and advise it does not 2020;13:1677-1686. affect the results of the paper.

The authors have advised Figure 3 on page 1682 is incorrect. Due to an error at the time of figure assembly Figure 2 and Figure 3 were duplicated. The correct Figure 3 is shown below.

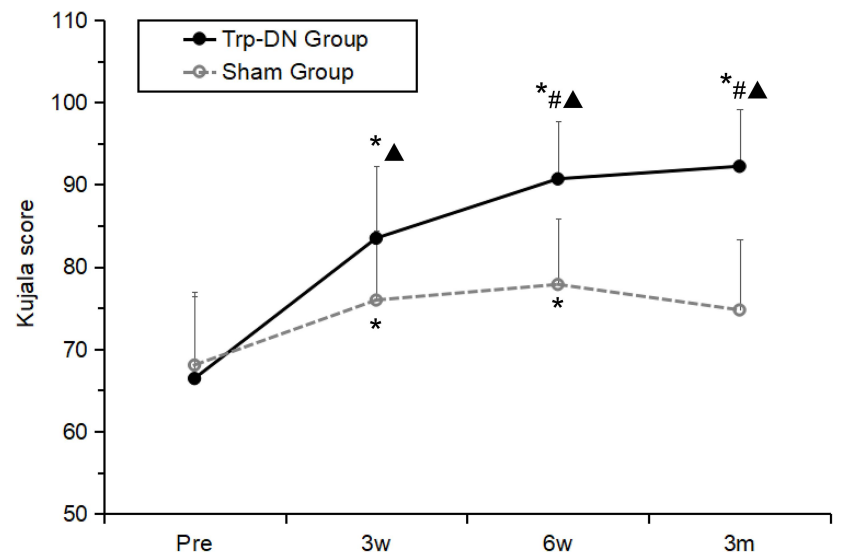

Figure 3 The Kujala scores in the TrP-DN group and the Sham group.

Notes: *Compared with the same group at pre-treatment $p<0.05$, " compared with the same group at 3 weeks after treatment $p<0.05,{ }^{\wedge}$ compared with the control group $p<0.05 . n=25$ in the TrP-DN group; $n=23$ in the Sham group.

Abbreviations: TrP-DN, trigger point dry needling; Pre, Pre-treatment; $3 \mathrm{w}, 3$ weeks after treatment; $6 \mathrm{w}, 6$ weeks after treatment; $3 \mathrm{~m}, 3$ months after treatment.

\section{Publish your work in this journal}

The Journal of Pain Research is an international, peer reviewed, open access, online journal that welcomes laboratory and clinical findings in the fields of pain research and the prevention and management of pain. Original research, reviews, symposium reports, hypothesis formation and commentaries are all considered for publication. The manuscript management system is completely online and includes a very quick and fair peer-review system, which is all easy to use. Visit http:// www.dovepress.com/testimonials.php to read real quotes from published authors. 